\title{
Evaluation of CA 15-3, Her-2/neu and estrogen/progesterone status in breast cancer patients treated by surgical removal and chemotherapy
}

\author{
Taha H Taha Al-siagh*, Shahbaa A Al-bayati**, Faris A Ahmed ${ }^{* *}$ \\ Departments of * surgery, **Physiology, Ninevah college of Medicine, University of Mosul
}

$\frac{\text { Received }}{20.2 .2012} \quad \frac{\text { Accepted }}{11.3 .2012}$

\section{ABSTRACT}

Objective: This study was conducted to evaluate serum CA 15-3 in breast cancer patients after surgery and chemotherapy. The relationship between serum CA 15-3 and Her-2/neu, estrogen, or progesterone receptors were also studied in the breast cancer patients.

Patients and methods: This study was conducted at Al-Jammhori Teaching Hospital, and Al-Zahrawi Private Hospital, Mosul, Iraq, during the period from January to Jun 2011. Fifty breast cancer women diagnosed by using triple assessments by a surgeon (history examination, ultrasound mammography, and fine needle aspiration cytology) were included in the study. Blood samples $(5 \mathrm{~mL})$ were taken from the patients and analyzed for serum CA 15-3 by monoclonal antibody technique. The blood samples were taken from the patients a week before and after one week of the operation and other blood samples were taken after two weeks of the first cycle of chemotherapy treatment. Combination therapy of 5-fluorouracil, epirubicin, cyclophosphamide, for three cycles every 21 days, was given to the patients, followed by three cycles docytaxil every 21 days. Samples from the tumor on paraffin sections taken from the patients were analyzed for Her-2/neu, estrogen and progesterone receptors by immunochemical methods.

Results: Serum CA 15-3 was significantly decreased by 54\% $(p \leq 0.001)$ after surgical removal of the cancer compared with results before surgery. Chemotherapy of the patients further decreased serum CA 15-3 significantly by 78\% $(p \leq 0.001)$ compared with the results before surgery. CA 15-3 and tumor size in positive Her$2 /$ neu patients were significantly higher than in negative Her-2/neu patients. However, serum CA 15-3 and tumor size in positive estrogen patients were significantly lower than in negative estrogen patients. In progesterone positive patient's serum CA 15-3 was only significantly $(p \leq 0.001)$ lower than in the negative progesterone patients. Mean ages was significantly $(p \leq 0.001)$ higher in positive Her-2/neu patients than in negative Her-2/neu patients. However, mean ages was significantly $(p \leq 0.001)$ higher in positive estrogen and progesterone patients than in negative receptors. Metastasis occurred in 39 patients $(78 \%)$ out of the studied patients. Negative significant correlation was noticed between Her $2 /$ neu and estrogen receptors $(r=-0.745, p \leq$ 0.001 ). Negative significant correlation was also noticed between Her $2 /$ neu and progesterone receptors $(\mathrm{r}=-0.786, p \leq 0.001)$. Weak but significant correlation was found between serum CA $15-3$ and tumor size $(r=0.281, p \leq 0.05)$. 
Conclusion: CA 15-3 and Her 2/neu are useful tumor markers for diagnosis of breast cancer in the treatment through surgery and chemotherapy. The co-expression between hormonal and Her-2/neu receptors is negative. The need for more sensitive tumor markers is still wanted.

الخلاصة

الهُف: تهذف هذه الدر اسة تقييم مصل دم CA 15-3 في المرضى المصابين بسرطان الثدي بعد الجر احة وبعد

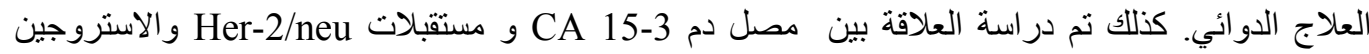

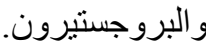

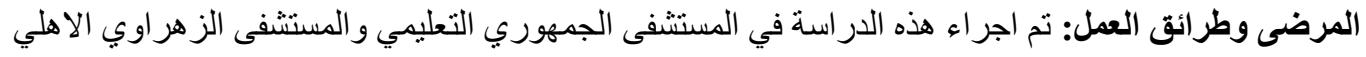

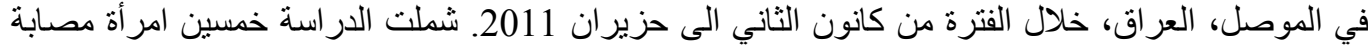

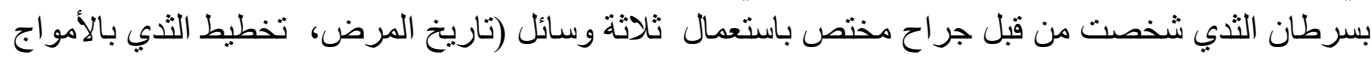

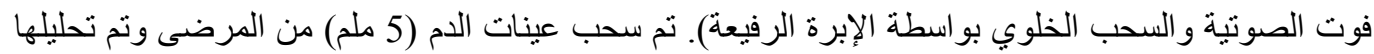

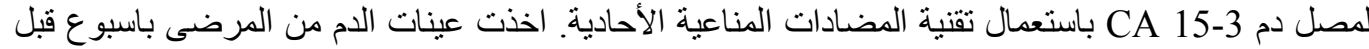

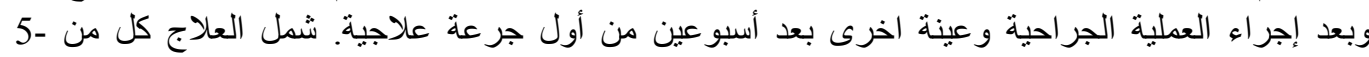
fluorouracil, epirubicin, cyclophosphamide

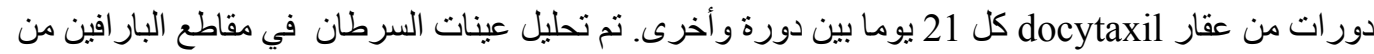

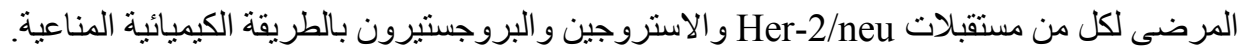
النتائج: كان مصل دم بتللك النتائج قبل العملية. وقلل العلاج السرطاني للمرضى مصل دمل دم

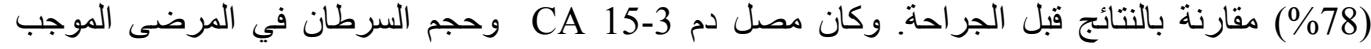
مستقبلات Her-2/neu اعلى معنويا بمستوى دلالة

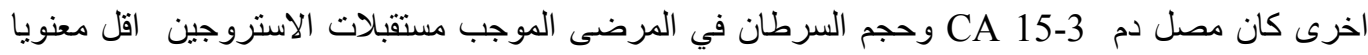

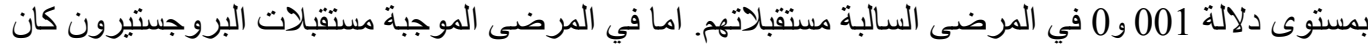

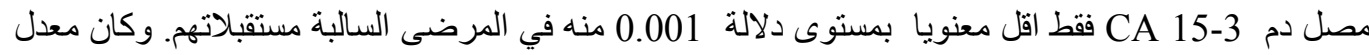

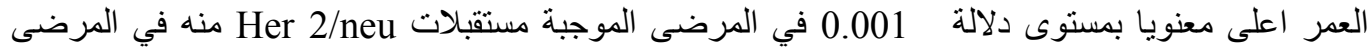

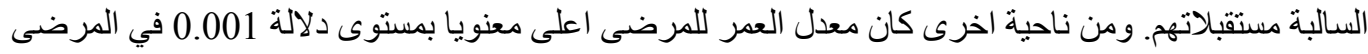

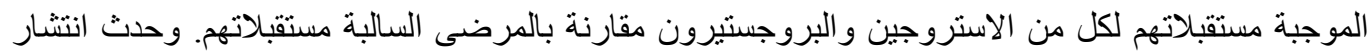

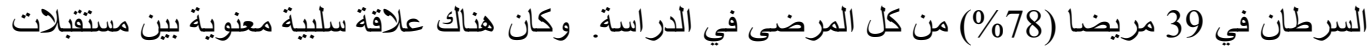

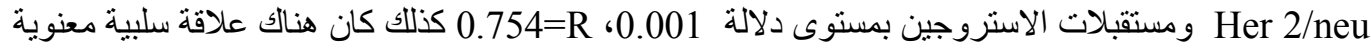

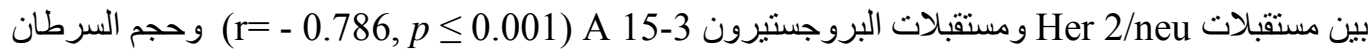

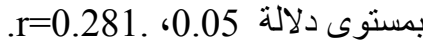
الاستنتاج: ان مصل دم CA 15-3 ومستقبلات Her 2/neu هو مفيد في تشخيص سرطان الثدي عند العلاج عن طريق الجراحة والعلاج الدوائي. وان العلاقة بين مستقبلات الهرمونات ومستقبلات Her 2/neu سلبية.

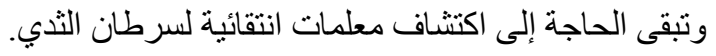

W umber of tumor associated monitoring or detecting breast cancer. CA $15-3$ is the product of Mucin-1 gene, and mucin are aberrantly over expressed in many adenocarcenoma in an underglycoslated form and then shed into the circulation ${ }^{1}$. CA $15-3$ appears to be useful and more effective $^{2}$.

There have been reports showing worse prognosis in patients with high concentration of CA 15-3 $3^{3}$. CA 15-3 has been shown to be an independent predictor of first recurrence as well as a powerful prognostic indicator in 
patients with advanced breast cancer ${ }^{4}$. Although its usefulness remains uncertain and American Society of Clinical Oncology guideline do not recommend its use for follow up ${ }^{5}$.

Her-2/neu oncogen has been extensively investigated as a prognostic factor as recently as a predictor of response to chemotherapy or endocrine therapy ${ }^{6}$. Over expression/amplication of the Her$2 /$ neu has been associated with worse outcome in patients with breast cancer ${ }^{7}$.

Tumor that express both estrogen and progesterone receptor have the greatest benefit from hormonal therapy and help physicians for therapy ${ }^{8}$. Negative estrogen and progesterone tumors tend to be of high grade and have worse prognosis ${ }^{9,10}$. There is negative correlation between hormone receptor expression and Her-2/neu amplification, but not all high grade breast cancer showed Her-2/neu positive status ${ }^{11}$.

This study was conducted to evaluate serum CA $15-3$ in breast cancer patients after surgery and chemotherapy. The relationship between serum CA 15-3 and Her2/neu, estrogen, or progesterone receptors were also studied.

\section{Patients and methods}

This study was conducted at AlJammhori Teaching Hospital, and AlZahrawi Private Hospital, Mosul, Iraq, during the period from January to Jun 2011. Fifty breast cancer women diagnosed by using triple assessments by a surgeon (history examination, ultrasound mammography, and fine needle aspiration cytology) were included in this study. The patient ages ranged between 22 to 85 years (mean \pm s.d: $48.3 \pm 14.7$ years).

Blood samples $(5 \mathrm{~mL})$ were taken from the patients and analysed for serum CA $15-3$ by monoclonal antibody technique (Minividas, USA, kids by Biomerieux company, France). The blood samples were taken from the patients a week before operation and also after one week of the operation. Other blood samples were taken after two weeks of the first cycle of chemotherapy treatment. Combination therapy of 5 -fluorouracil $500 \mathrm{mg} / \mathrm{m}^{2}$, epirubicin $100 \mathrm{mg} / \mathrm{m}^{2}$, and cyclophosphamide $500 \mathrm{mg} / \mathrm{m}^{2}$, for three cycles every 21 days, was given to the patients, followed by three cycles docytaxil $100 \mathrm{mg} / \mathrm{m}^{2}$ every 21 days. Patients in immune histochemical staining for Her-2/neu positive were given trazotozumab 6 $\mathrm{mg} / \mathrm{Kg}$ BW with docytaxil every 21 days for one year started after 21 days of the last dose of docytaxil cycle. Samples from the tumor on paraffin sections taken from the patients were sent to Histopathology Department in Al-Jammhori Teaching Hospital and analysed for Her 2, estrogen and progesterone receptors by immunochemical method (Dako company, Danemark).

Data are presented as mean \pm s.d. and were analyzed by using paired ttest to compare the follow up parameters. Q squire test was used to compare non-parametric measurements. SPSS package version 17 was used for analysis. 


\section{Results}

Table 1. Serum CA 15-3 in breast cancer patients under surgical and chemotherapy treatment $(\mathrm{n}=50)$

\begin{tabular}{|c|c|}
\hline Patients & CA $15-3(\mathrm{U} / \mathrm{mL})$ \\
\hline Before surgery & $84.42 \pm 19.08$ \\
\hline After surgery & $38.88 \pm 13.77^{\mathrm{a}}$ \\
\hline sAfter chemotherapy & $18.62 \pm 12.29^{\mathrm{b}}$ \\
\hline
\end{tabular}

${ }^{\mathrm{a}} p \leq 0.001$ vs before surgery, ${ }^{\mathrm{b}} p \leq 0.001$ vs before surgery

Table 1 shows that serum CA 15-3 was significantly decreased $(p \leq 0.001)$ after surgical removal of the cancer compared with results before surgery. Chemotherapy of the patients further decreased serum CA 15-3 significantly $(p \leq 0.001)$ compared with the results before surgery.

Table 2 shows that CA $15-3$ and tumor size in positive Her-2/neu patients were significantly higher than in negative Her-2/neu patients. However, serum CA 15-3 and tumor size in positive estrogen patients were significantly lower than in negative estrogen patients. In progesterone positive patient's serum CA $15-3$ was only significantly $(p \leq 0.001)$ lower than in the negative progesterone patients. Mean ages was significantly $(p \leq 0.001)$ higher in positive Her-2/neu patients than in negative Her-2/neu patients.
However, mean ages was significantly $(p \leq 0.001)$ higher in positive estrogen and progesterone patients than in negative receptors.

Metastasis was found in 39 patients $(78 \%)$ out of the studied patients (node, lung, liver, or bone). Thirty four out of 50 of the patients were married and the number of children for these patients was between 0 and 7 children.

Negative significant correlation was noticed between Her-2/neu and estrogen receptors $(\mathrm{r}=-0.745, p \leq$ $0.001)$. Negative significant correlation was also noticed between Her-2/neu and progesterone receptors $(\mathrm{r}=-0.786$, $p \leq 0.001)$. Weak but significant correlation was found between serum CA $15-3$ and tumor size $(r=0.281, p \leq$ 0.05 )

Table 2. Serum CA 15-3 in breast cancer patients with positive and negative Her $2 /$ neu, estrogen and progesterone receptors $(n=50$ for all patients)

\begin{tabular}{|c|c|c|c|c|}
\hline Receptors & $\mathrm{n}$ & CA 15-3 $(\mathrm{U} / \mathrm{mL})$ & $\begin{array}{c}\text { Tumor size } \\
(\mathrm{cm})\end{array}$ & Age (years) \\
\hline Her 2/neu (positive) & 19 & $100.47 \pm 12.94$ & $4.63 \pm 2.41$ & $40.8 \pm 9.8$ \\
\hline Her 2/neu (negative) & 31 & $74.03 \pm 12.41^{* *}$ & $2.58 \pm 1.89^{*}$ & $53.1 \pm 15.1^{* *}$ \\
\hline Estrogen (positive) & 31 & $76.39 \pm 16.39$ & $2.74 \pm 1.84$ & $52.5 \pm 14.9$ \\
\hline Estrogen (negative) & 19 & $99.37 \pm 14.44^{* *}$ & $4.37 \pm 2.67^{*}$ & $41.8 \pm 11.8^{* *}$ \\
\hline Progesterone (positive) & 32 & $76.97 \pm 15.96$ & $2.32 \pm 2.32$ & $52.2 \pm 15.3$ \\
\hline Progesterone (negative) & 18 & $99.56 \pm 15.98^{* *}$ & $4.11 \pm 2.23$ & $41.7 \pm 10^{* *}$ \\
\hline
\end{tabular}

$* p \leq 0.05$ vs values with positive receptors, ${ }^{*} p \leq 0.001$ vs values with positive receptors 


\section{Discussion}

In the present study, serum CA 15-3 was decreased significantly after surgical removal of the cancer, chemotherapy further significantly decreased serum CA 15-3. These results are consistent with other workers $^{12}$. High preoperative CA 15-3 and CEA levels may reflect tumor burden and are associated with advanced disease and poor outcome ${ }^{13}$. CA $15-3$ is particularly valuable for treatment monitoring in patients that have disease that cannot be evaluated using existing radiological procedure ${ }^{14}$. However, pre-operative serum CA 153 measurement is of little value, especially in patients with early stage breast cancer and are not useful in the therapeutic decision-making of patients with breast cancer ${ }^{15}$. In addition, the time elapsed between CA 15-3 increase and clinically confirmed progression was very short for follow up study ${ }^{16}$.

In Her-2/neu positive patients, serum CA 15-3 was significantly higher than in Her-2/neu negative patients. Overexpression/amplification of the Her 2/neu has been associated with a worse outcome in patients with breast cancer ${ }^{7}$. CA 15-3 was associated with age, tumor size, nodal involvement, and Her 2 expression ${ }^{17}$. Serum Her 2 and CA 15-3 in breast cancer were useful markers for predicting aggressive behavior of tumor and elevated serum levels are associated with breast cancer relapse 12. The combination of the increased serum Her-2/new and increased serum CA 15-3 predicts a worse prognosis than increased CA 15 alone $^{18}$.
Metastasis of cancer was high $(78 \%)$ in the present patients. It is commonly accepted that the earlier the detection of the disease the better the prognosis. Estrogen, progesterone, and Her-2/neu receptors are independent prognostic factors for locoregional recurrence and survival in node positive breast cancer patients treated by mastectomy ${ }^{19}$. These biomarkers showed signifacant concordance between primary tumors and lymph node metastasis ${ }^{20}$. Moreover, the survival analyses showed that the expression of biomarkers in lymph node metastasis can provide prognostic information when no analysis of primary tumor can be done ${ }^{21}$. CA $15-3$ provided significant additional information to the common prognostic factors to predict the occurrence of metastasis ${ }^{17}$.

In the present study, serum CA 153 was significantly lower in the hormonal positive patients than in the negative hormonal patients. The positivity rates of serum CA 15-3 significantly correlated with estrogen and progesterone status ${ }^{22}$.

Negative significant correlation was noticed between the present Her$2 /$ neu and estrogen or progesterone receptors. These results are consistent with other workers ${ }^{23,24}$. However, the co-expression of hormonal receptors with Her-2/neu is infrequent ${ }^{25}$. Her-2 was associated with bad prognosis and correlated with the grade of tumor ${ }^{6,26}$. High grade tumors tend to be estrogen negative and Her-2 positive, estrogen negative tumors tend to be of high grade and worse prognosis tumors ${ }^{10}$.

In the present study, mean ages in the Her-2/neu positive was 
significantly lower than that in negative receptors. However, ages were significantly higher in hormonal positive receptors than that in the negative receptors. No correlation was found between Her-2 receptor and ages of the breast cancer patients ${ }^{24}$.

In conclusion, CA 15-3 and Her $2 /$ neu are useful tumor markers for diagnosis of breast cancer through surgery and chemotherapy. The coexpression between hormonal and Her-2/neu receptors is negative. The need for more sensitive tumor markers is still wanted.

\section{References}

1- Perey L, Hayes D F, Maimonts P, et al. Tumor selective reactivity of a monoclonal antibody prepared against a recombinant peptide derived from the DF3 human breast carcinoma-associated antigen. Cancer Res 1992;52:2563-8.

2- Maric P, Ozretic P, Levanat S, et al. Tumor marker in breast cancerelevation of their clinical usefulness. Coll Antropd 2011;35:241-7.

3- Molina R, Filella X, Alicarte J, et al. Prospective evaluation of CEA and CA 15-3 in patients with locoregional breast cancer. Anticancer Res 2003;23:1035-41.

4- Berruti M, Tampellini M, Torta M, et al. Prognostic value in predicting overall survival of two mucinous markers: CA 15-3 and CA 125 in breast cancer patients at first relapse of disease. Ann Oncol 2008;19:675-81.

5- Bast RC, Ravdin P, Haves DF et al. 2000 update recommendation for the use of tumor markers in breast and colorectal cancer: clinical practice guidelines of the American Society of Clinical Oncology. J Clin Oncol 2001;19:1865-1878.

6- Hanna W, Kahn HJ, TH, Trudeau M. Evaluation of Her-2/neu (erB-2) status in breast cancer: from bench to bedside. Mod Pathol 1999;12:827-34.

7- Kaptain S, Tan LK, chen B. Her2/neu and breast cancer. Diagn Mol Path 2001;10:139-52.

8- Osborn CK. Steroid hormone receptors in breast cancer management. Breast Cancer Res Treat 1998;51:227-38.

9- Baqai T, Shousha S. Oestrogen receptor negativity as a marker for high-grade ductal carcinoma in situ of the breast. Histopathology 2003;42(5):440-7.

10-Misek DE, Kim EH. Protein biomarkers for the early detection of breast cancer. Int Proteomics 2011;2011:34582.

11-Arafah M. Correlation of hormone receptors with Her-2 Neu protein expression and the histological grade in invasive breast cancers in a cohort of Saui Arabia. Turk Patoloji Derg 2012;28:38-43.

12-Samy N, Ragah HM, El-Maksoud NA, Shaalan M. Prognostic significance of serum Her-2/neu, BCL2, CA 15-3 and CEA in breast cancer patients: a short follow up. Cancer Biomark 2010;6:63-72.

13- Park BW, Oh J W, Kim J H, et al. Preoperative CA 15-3 and CEA serum levels as predictor for breast cancer outcomes. Oxford J Med Oncol 2007;19:675-81.

14-Duffy MJ, Evoy D, McDermott EW. CA 15-3: uses and limitation 
as a biomarker for breast cancer. Clin Chim Acta 2010;411:1869-74.

15-Lumachi F, Basso SM, Brandes $\mathrm{AA}$, et al. Relationship between tumor markers CEA and CA 15-3, TNM staging, estrogen receptor rate and MIB-1 index in patients with pT-2 breast cancer. Anticancer Res 2004;24:3221-4.

16-Einarsson R, Lindman H, Bergh J. Use of TPS and CA 15-3 assays for monitoring chemotherapy in metastatic breast cancer patients. Anticancer Res 2000;20:5089-93

17-Sandri MT, Salvatici M, Botteri E, et al. Prognostic role of CA15.3 in 7942 patients with operable breast cancer. Breast Cancer Res Treat 2012;132(1):317-26.

18-Ali SM, Leitzel K, Chinchilli VM, et al. Relationship of serum HER2/neu and serum CA $15-3$ in patients with metastatic breast cancer. Clin Chem 2002;48:131420.

19- Wang SL, Li YX, Song YW, et al. Prognostic value of estrogen receptor, progesterone receptor and human epidermal growth factor receptor-2 in node positive breast cancer patients treated by mastectomy. Zhonghua Zhong Liu Za Zhi 2010;32(7):520-5.

20-Azam M, Qureshi A, Mansoor S. Comparison of estrogen receptors, progesterone receptors and Her2/neu expression between primary and metastic breast carcinoma. J pak Med Assoc 2009;59:736-40.
21-Falck AK, Fernö M, Bendahl PO, Rydén L. Does analysis of biomarkers in tumor cells in lymph node metastases give additional prognostic information in primary breast cancer? World J Surg 2010 Jul;34(7):1434-41.

22-Nishimura R, Nagao K, Miyayama $\mathrm{H}$, et al. Elevated serum CA 15-3 levels correlate with positive estrogen receptor and initial favorable outcome in patients who died from recurrent breast cancer. Breast cancer 2003;10:220-7.

23- Taucher S, Rudas M, mader RM, et al. Do we need Her-2/neu testing for all patients with primary breast carcinoma? Cancer 2003;98:254753.

24- Ariga R, Zarif A, Korasick J, et al. Correlation of her-2/neu gene amplification with other prognostic and predictive factors in female breast. carcinoma. Breast J 2005;11:278-80.

25-Ciocca DR, Gago FE, Fanelli MA, Calderwood SK. Co-expression of steroid receptors (estrogen receptor alpha and/or progesterone receptors) and Her-2/neu: Clinical implications. J Steroid Biochem Mol Biol 2006;102:32-40.

26- Ramadan SS, Yapicier O, Kihtir S, et al. Correlation of Her 2/neu gene amplification with immunohistochemistry and other prognostic factors in breast carcinoma. Turk Patoloji Derg 2011;27:196-203. 